\title{
OF BENEVOLENCE AND UNITY: UNPACKING CHINA'S FOREIGN POLICY DISCOURSES TOWARD SOUTHEAST ASIA
}

\author{
Enrico V. Gloria \\ Department of Political Science, College of Social Sciences and Philosophy \\ University of the Philippines Diliman, Quezon City, Metro Manila \\ evgloria@up.edu.ph
}

Received: $03^{\text {rd }}$ February $2021 /$ Revised: $12^{\text {th }}$ May 2021/ Accepted: $17^{\text {th }}$ May 2021

How to Cite: Gloria, E. V. (2021). Of benevolence and unity: Unpacking China's foreign policy discourses toward Southeast Asia. Journal of ASEAN Studies, 9(1), 1-23, https://doi.org/10.21512/jas.v9i1.7037

\begin{abstract}
While much attention has been directed on the security and economic implications of China's rise in the region, research on the normative implications of China's persistent attempt at projecting a positive major power identity continue to be lacking. This paper seeks to contribute to this growing literature, as it applies Social Identity Theory (SIT) in analyzing China's discourses toward Southeast Asia from Mao to Xi. More specifically, it unpacks social identity phenomena within discourses reflected in official documents by using predicate analysis. Insights from the findings of this paper underscore China's growing role as a normative power driven by a longstanding objective to be perceived positively and distinctively. Likewise, this paper also finds that there is a continuity with respect to China's foreign policy discourse of depicting Sino-Southeast Asia relations as unique and united. There are also indications that Southeast Asia has consistently been presented as benefiting from its relations with China, thereby treating it as a prototype of what a Sino-centric order might offer for the rest of the world. Ultimately, China's discourses of itself, Southeast Asia, and Sino-Southeast Asia relations point to major power aspirations of constructing a united in-group and a positive identity.
\end{abstract}

Keywords: China's Foreign Policy, Southeast Asia, Sino-Southeast Asia Relations, Social Identity Theory, Discourse Analysis 


\section{INTRODUCTION}

How do we make sense of China's foreign policy discourse toward Southeast Asia since the founding of the People's Republic? How have China's discourses toward the region further its objective of presenting a positive and unique identity as a major power? This paper seeks to provide a discussion of China's foreign policy discourses toward Southeast Asia as reflected in its official foreign policy pronouncements since the founding of the PRC. Indeed, SinoSoutheast Asia relations since Mao Zedong's leadership has gone through considerable changes in terms of imperative global issues and domestic political developments. But despite these changes, this paper takes the critical assumption that Southeast Asia remains a consistent focus for China with respect to its overall foreign policy direction. And given China's growing influence in the region, it is important to take a more comprehensive appreciation of how China has represented and thought of Southeast Asia with respect to its overall foreign policy logic.

Southeast Asia plays a unique role in China's foreign policy. China's current leadership under Xi Jinping has been consistently straightforward in highlighting Sino-Southeast Asia relations as a "priority" region "in its relations with developing countries" and in China's overall "peripheral diplomacy" (MOFA, 2013; Li, 2013; Xi, 2015a; Li, 2020a). For instance, the idea of a Maritime Silk Road Initiative (MSRI) bore out of what China considers as Southeast Asia's important role along its ancient silk route, thereby prioritizing the region in the establishment of this initiative (Xi, 2013). And as argued by Jeffrey Reeves (2018) in his study of Xi Jinping's peripheral diplomacy, the current leadership "has made peripheral relations central to all its flagship foreign policy concepts” (p. 977).

Apart from narratives and concepts, the current strategic reality of Sino-Southeast Asia relations also provides evidence on the region's uniqueness and significance for China. It has been noted that China has been making "unprecedented inroads" in prioritizing new security partnerships with ASEAN countries, which points to the region's importance in China's geopolitical ambitions (Parameswaran 2020). In terms of economic relations, ASEAN-China trade grew by $7 \%$ despite the global health and economic crisis, making ASEAN as China's largest trading partner for the first time. This is a further testament not just to the resilience of Sino-Southeast Asia cooperation, but also to China's growing concentration on the region. China has also never failed to underscore that it is consistently the "first" major power to lodge support in various ASEAN initiatives-- from acceding to ASEAN's Treaty of Amity and Cooperation, to the launching of an ASEAN-China free trade area (Li, 2013b). And with respect to managing the current pandemic, China has also hinted on motivations to prioritize Southeast Asia in receiving COVID-19 vaccine donations (Li, 2020b; Strangio, 2020; Tan and Maulia, 2020). Indeed, compared to other partnerships, Southeast Asia as a region plays a unique role in China's overall external relations as it is the logical recipient or "testing ground" for China to channel the expansion of its power and influence (Stromseth, 2019). This makes it important for observers of China's foreign policy to focus on Sino-Southeast Asia relations for a more nuanced understanding of China's continuous ascent to major power status. 


\section{LITERATURE REVIEW}

Currently, mainstream explanations on China's foreign policy logic in Southeast Asia tend to assume the realist logic that its behavior is simply informed by a much larger major power competition for regional hegemony between China and the United States (see Beeson and Li, 2012; Xinbo, 2016; Suehiro, 2017; Kim, 2014). Li Xiaoting (2015) for instance argues that China uses its growing capabilities to "seek the assistance of its neighbors in turning away a rival great power from China's periphery" (p. 25). Other scholars forward this argument by focusing on great power influence as currency to purchase small neighbor allegiance in the face of the Sino-US geopolitical competition (Huong, 2019; Rüland and Michael, 2019; Storey, 2012). Overall, this group of observations stems from a realist logic of considering Southeast Asia solely as an arena of major power competition, thereby treating Sino-Southeast Asia relations as the zero-sum counterpart of US-Southeast Asia alliance.

Another set of explanations rooted in a similar realist logic highlights China's 'core national interests' as the primary motivation for restraint or assertiveness observed in China's behavior toward the region. As Rumi Aoyama (2013) argues, "the simultaneous achievement of three national interests of security, sovereignty, and economic development" influences China's foreign policy in the neighborhood (p. 91). While this group tend to highlight a perceived proclivity for peace and non-aggression as a significant factor in determining the shape and form of China's behavior toward Southeast Asia, these explanations are rooted in an assumption that China's national interests come first, especially those concerning its economic development at home (Takahara, 2012; Boon, 2017; Goh, 2014). In this sense, national interest trumps other potential variables that may also explain China's foreign policy in Southeast Asia.

Despite mainstream realist explanations on China's foreign policy in the region, there are those who also highlight the importance of norms, ideas, and discourses in understanding China's Southeast Asia approach. As Song Weiqing (2020) has argued in his research on China's multilateral engagements in Asia, he claims that China's rise in the region is also informed by a "growing normative agenda" which therefore makes China a "normative foreign policy player" as it strives to dictate values and behavior that can be considered as "normal" hence shaping the way international relations ought to be conducted (p. 231). This group of explanations tends to highlight China's pursuit for non-material gains such as identity and status beyond security calculations (see Smith, 2021; Gloria, 2020; Callahan, 2016; Qin, 2006).

Lastly, and related to the above constructivist explanations emphasizing non-material gains, there is also a growing attempt in the literature to highlight the consequential role of Southeast Asia and how it is an important arena for China as it aspires to become a normative and distinct major power vis-à-vis western powers in history. As argued by William Callahan (2016), the current leadership under Xi seeks "to forge a new network" in Southeast Asia "guided by Chinese values" which ultimately serves the "much larger end of promoting China's new vision of global governance" (pp. 13-14). Song (2020) and Reeves (2018) also concur with this observation highlighting an increasingly prominent Sino-centric network in Southeast Asia ushered in by the normalization of specific norms and ideas, which in turn seeks to reshape the greater regional and global order. For these scholars, Southeast Asia acts as a 
convenient 'prototype' for China in terms of showing the world how a Sino-centric order, founded on benign values and benevolent major power identity, may work for the future.

This paper seeks to contribute to the above constructivist literature, as it takes the assumption that China's foreign policy discourses on Southeast Asia have been guided by more persistent objectives of presenting a positive and distinct identity as a benign normative power. More specifically, this research aims to contribute to the ongoing scholarly discussion on SinoSoutheast Asia relations in two ways. First, it refers to Social Identity Theory (SIT) as a fitting theoretical framework in analyzing how identity manifested through discourse prevails in China's foreign policy thinking toward Southeast Asia. As discussed in the next section, there is a growing literature on the application of SIT in international relations and Chinese foreign policy, but none yet in terms of a specific application in understanding Sino-Southeast Asia relations. Second, the paper also attempts to provide a much larger scope hence an overview of China's foreign policy discourse towards Southeast Asia as it focuses on sample documents and excerpts in conducting its discourse analysis of official texts since the leadership of Mao Zedong. In this way, the findings of this paper allows for an identification of discursive continuities and changes, which is similar to what has been done in other explanations of Chinese foreign policy (see Qin, 2014; Li, 2019). While the existing literature have yet to make a systematic attempt at a more specialized focus on discourse and Southeast Asia as subjects of interest, this research does not promise a definitive interpretation of China's overall discourse in the region. Following a discussion of SIT, the paper proceeds with an explanation of how discourse analysis was conducted in a sample of texts.

\section{ANALYTICAL FRAMEWORK}

Social Identity Theory is one of the main theoretical developments in social psychology, which primarily deals with the study of intergroup relations. Its main assumption, as far as its applicability in the discipline of International Relations is concerned, is the centrality of social identity or status in determining prospects for conflict and cooperation. Social identity, as defined by Henri Tajfel and John Turner (1986), refers to "those aspects of an individual's selfimage that derive from the social categories to which an individual perceives himself as belonging" (p. 277). SIT assumes that individuals naturally aspire a positive social identity or self-image, the evaluation of which is relative to how it perceives a significant out-group or an 'Other' (p. 288). Applying SIT to IR, states such as China are assumed to also undergo social identity phenomena of seeking to achieve a positive and distinct identity.

To uncover social identity phenomenon at work as internalized by the 'Self' or the 'ingroup', the underlying socio-cognitive processes of categorization and self-enhancement must be initially articulated and identified. The process of categorization refers to how the 'Self' or the state in question assigns and affiliates itself to a relevant category or grouping, and how the boundary between itself and the out-group is consequently sharpened through "groupdistinctive stereotypical and normative perceptions" (Hogg, M., Terry, D., \& White, K., 1995 p. 260). For the purposes of benchmarking other actors, this category or grouping is represented by a particular prototype, which may be a subset of the in-group that equates to an exemplary 
representation of the distinctive qualities of the larger in-group. The prototype essentially allows the in-group to judge potential members, and to further enhance the group's entire image as discriminatory comparisons with the out-group are made. The latter refers to the process of Self-enhancement. More specifically, this process requires specific positive-negative comparisons to be made between an in-group and out-group, which results to improved selfesteem as it magnifies a positive depiction of the 'Self' relative to the 'Other'(Hogg et al, 1995 pp. 260-261).

This paper assumes that China, through the discourses it has promoted on its foreign policy and relations with Southeast Asia, exhibits social identity behaviors akin (1) to categorizing itself within a self-constructed in-group and, (2) to enhancing a positive major power image and status in contrasting itself from an out-group of western major powers. Moreover, there are also indications that this constructed Sino-Southeast Asia in-group unity is treated as a prototypical in-group as China seeks to universalize the norms and ideas it has consistently promoted, thus consistent with the observations made by existing literature on China's normative power. Overall, this paper adds to the growing literature on SIT's application in nuancing Chinese foreign policy (see Yi, 2020; Gloria, 2020; Larson, 2017; Lee, 2016; Larson and Schvenchko, 2014; Gries, 2005). Most of them had hitherto focused on the implications of SIT in understanding China's rise vis-a-vis major power competition by emphasizing different 'identity strategies' China undertakes as it aspires for top major power status. This paper takes a slightly different direction as it considers the initial social identity process (categorization and self-enhancement, as well as prototyping) which existing studies have not sufficiently touched upon. The paper also contributes to the growing SIT-IR literature by also focusing on a much narrower subject of study such as Sino-Southeast Asia relations.

\section{RESEARCH METHOD}

Another crucial assumption that this paper takes is that "identity construction" and 'Self-Other' distinctions are manifested in discourse, and therefore can be uncovered using discourse analysis (Lindgren \& Lindgren, 2017 p. 381; also see Van Dijk, 2001; Wodak, 2001). Discourse as conceptualized in this paper is consistent with Michel Foucault's (1972) understanding that language depicts modes of representation that serve to establish domains of knowledge. Related to this, "social representations in the mind of social actors" regarding the 'Self' and 'Other' are treated as the "theoretical interface" linking power and discourse, thus making discourse and identity simultaneously occurring (Van Dijk, 1993 p. 251). Therefore, consistent with SIT, social cognition and representation, or the way states think about their place in international society, becomes an important element of understanding discourse.

The paper conducts its discourse analysis in a sample of publicly available high-level government documents describing China's foreign policy rationale in Southeast Asia. Purposive sampling was done to select few but information-rich sample texts (Schreier 2018, p. 88). This sampling decision and approach is guided by the main objective of presenting an in-depth description of the five paramount leadership-periods-- Mao Zedong, Deng Xiaoping, Jiang Zemin, Hu Jintao, and Xi Jinping-- and their respective distinct operational codes or 
foreign policy rationale (He and Feng, 2013). Consistent with the parameters of purposive sampling, identifying candidate documents were limited by a selection criteria that is practical yet consistent with the main research objective (Schreier 2018, 93). First, the selected documents were all obtained from open-access online repositories ensuring their wide availability. Second, the naturally occurring documents were either penned or articulated by high-level foreign policy officials (e.g. President, Premier, Vice President, Foreign Ministers, and Ambassadors) to ensure representativeness of a particular leadership policy legacy or operational code. And lastly, the subject focus of these documents pertain to a specific discussion of China's overall vision and main rationale for Sino-Southeast Asia relations. Limiting the selection search using this set of criteria yields a selection of a few sample documents that are homogenous for each of the five leadership-period, and are still relevant, representative, and information-rich (Patton 2014, p. 429). And to control for the differences resulting from variations in the number of publicly available documents within each leadership period, as for instance cold war leaderships would have relatively fewer documents that satisfy the criteria, a quota of three documents was determined to be sufficient given the objective of conducting an in-depth analysis of a few information-rich texts common in qualitative studies (see Crouch and McKenzie, 2006; Ruiz, 2009). Similarly, the three unique documents selected for each leadership-period were purposively determined based on their consistency with the identified criteria. Lastly, all official documents analyzed are English translations. While referring to official Chinese foreign policy documents do provide a closer approximation of the leaders' operational codes and logic, focusing on widely accessible English-language documents ensure that the specific descriptions unpacked are representations of relevant subjects (e.g. China, Southeast Asia) that China wants its foreign audience to specifically appreciate. Since social identity is about status curation and projection, texts meant for external audiences also fit the analytical logic of this research.

The focus is on uncovering salient discursive themes from the texts, which could point to the SIT phenomena of categorization and self-enhancement, and ultimately China's overall discourse of its foreign policy logic in Southeast Asia. These discursive themes are uncovered by conducting predicate analysis in reading the sample texts. Doing predicate analysis entails looking for discursive devices that assigns "stereotypical, evaluative attributions of negative and positive traits" to relevant subjects-- or the main actors in China's story-telling (Wodak 2001, p.73). The identified relevant subjects are (1) Sino-Southeast Asia relations, (2) China, (3) Southeast Asia, and (4) western major powers. Identifying and focusing on these four subjects is also consistent with the analytical objectives of SIT to uncover the "defining characteristics" of "social categories" or the perceived in-groups and out-groups, which in this case are broadly represented by the four subjects (Hogg et al 1995, p.259).

\section{ANALYSIS}

This section provides a discussion of the salient discursive themes from the sample texts that were uncovered through predicate analysis. The analyses below are guided by the following questions: (1) How has China described the subject, (2) What consistent themes in 
terms of common representations (i.e. predicates and descriptors) employed by various leaderships can be identified?

The first part focusses on how China predicated or described 'Sino-Southeast Asia relations' and the themes that they constitute. It is argued that ultimately, these themes make up China's specific 'discourse of unity' in terms of how it perceives Sino-Southeast Asia relations throughout the five leaderships. While there are notable changes in context and therefore the rallying point for in-group unity, what has been continuous is China's commitment to discursively portray China and Southeast Asia as belonging to a similar ingroup.

\section{Sino-Southeast Asia Relations and China's 'Discourse of Unity'}

China's reference to 'Southeast Asia' as a distinct group only occurred substantially in recent political history. More specifically, China under the leaderships of Mao Zedong, and Deng Xiaoping tend to describe and refer to Southeast Asia within the larger 'third world' or 'Asia' grouping. Indeed, this observation is consistent with the division of the three worlds that Mao Zedong has formally stipulated in 1974, specifically stating that "developing countries in Asia, Africa, Latin America and other regions belong to the third world" (Ministry of Foreign Affairs of the People's Republic of China, 2014).

On the other hand, clear reference to either a distinct Southeast Asian region, and ASEAN as a single political entity, only started appearing in official texts during the post-cold war period, beginning with Jiang Zemin's leadership. This is consistent with Joseph Cheng's (1999) observation that China during this period has started to consider ASEAN as one of the "poles in the multipolar power transfiguration in the Asia-Pacific region" (p. 177, also see Wong, 2007). This represents a shift towards a more increased focus and a more specialized approach on the region within China's foreign policy. Despite this obvious change, China's overall discourse towards Southeast Asia has been anchored on a continuous commitment to portray the two sides as being united as one in-group, as evidenced by four distinct discursive themes uncovered in this analysis. Indeed, regardless of the changing international circumstances and leaderships in the last 70 years, China has often described Sino-Southeast Asia relations on terms that evoke longstanding friendship and affinity. This points to China's cognitive representation of itself and Southeast Asia as belonging in the same in-group of likeminded nations.

\section{Discourse of Unity: Shared Legacies and Struggles}

The first theme under China's discourse of unity points to shared victimhood, as both sides have jointly been victims of western imperialism and underdevelopment. This idea of a shared victimhood has mostly been invoked by the cold war leaderships of Mao Zedong and Deng Xiaoping. For instance, speaking to then Indian Prime Minister Jawaharlal Nehru in 1954 on the overall conditions of Asia as a region, Mao Zedong stated that Asia as a whole is united by the "common experience" of having "suffered from foreign rule" (Mao, 1954a). And in 
Zhou Enlai's speech in front of the historic Asian-African Conference in 1955, he referred to the same discourse of common victimhood to make the point that the developing world "found it easier to understand each other and have long deep sympathy and concern for one another" because of this shared suffering (Zhou, 1955).

Continuing this story of shared victimhood, succeeding leaderships have also invoked the idea, although less prominently during Jiang Zemin's and Hu Jintao's regimes. As stipulated in Deng Xiaoping's description of "China's Foreign Policy of Peace", the "third world" have been "victims of hegemonism," thereby making "union and cooperation" to safeguard world peace and oppose hegemonism a rational group focus (1982). Likewise, Xi Jinping in 2013 also referred to the same discourse of a common struggle between China and ASEAN, stating that the two "had sympathized and supported each other in their respective struggle for national independence and liberation in the last century". Indeed, China has constantly pointed to this unique experience of being subjected to imperialism, or the general antagonism coming from the west, to argue for a natural affinity between Southeast Asia and China. And this only served to sharpen the group boundaries that constitute China's constructed in-group.

In addition to shared victimhood, China also turns to the discursive theme of shared historical legacies to solidify its claim to in-group affinity with Southeast Asia. For instance, it is common to find predicates within high-level speeches referring to China and Southeast Asia's long history of contacts, friendships, and overall good relations, thereby justifying ingroup affinity and solidarity (see Xi, 2013; Wen, 2011; Li, 2009; Jiang, 1997; Mao, 1963). Although this discursive theme emphasizing 'traditional friendship' can be uncovered in most high-level speeches since Mao's era, this is found to be most prominent in speeches under Hu Jintao's and Xi Jinping's leaderships. Xi Jinping in particular came to support the decision to make Southeast Asia a crucial component of the Maritime Silk Road Initiative (MSRI) owing to both sides" "long history" of friendship and contacts (2013). In addition to this, he would also describe longstanding neighborhood unity by referencing specific historical anecdotes and images that underpin a "history of amicable exchanges" between the two sides (Xi, 2015a). In the inaugural speech of the MSRI delivered in front of Indonesian legislators, the Chinese leader points to the voyages of Admiral Zheng He as testament to "stories of friendly exchanges" between China and the peoples of Southeast Asia (2013). Extending this pattern of referring to history, Premier Wen Jiabao (2011) under the previous leadership talked about how ASEAN and China "enjoy geographical, cultural, and historical proximity" and pointed to cherishing "traditional friendly ties" as part of the usual assessment of ASEAN-China relations. Just like with what was observed in China's shared victimhood discourse, this constant reference to shared historical legacies constitutes a discursive theme in itself that serves to solidify China's claim to having a natural in-group affinity with Southeast Asia.

A contemporary version of the above representations of in-group unity has also emerged, owing to transnational challenges posed by the post-cold war order. China has also turned to shared struggles as a discursive theme to depict in-group solidarity amidst emerging transnational issues. For instance, then Vice President Hu Jintao (1998) under the leadership of Jiang Zemin, recalled in his speech to the ASEAN summit how China and ASEAN "have 
pulled together in times of trouble and supported one another" during the Asian financial crisis. Succeeding leaderships of $\mathrm{Hu}$ Jintao and Xi Jinping have also frequently referred to this shared experience of surviving the financial crises to emphasize China-ASEAN solidarity (Wen, 2011; Tong, 2011; Li, 2009; Xi, 2013, 2015; Li, 2020). In other instances where this discourse of shared experiences have been utilized, China-ASEAN bilateral relations was described as being cooperative towards each other, especially when it comes to jointly "responding to major natural disasters" as well as "controlling such communicable diseases such as SARS and avian influenza" (Tong, 2011). Almost a decade after, this narrative of jointly combatting transregional issues finds its way in Li Keqiang's most recent speech delivered during the 2020 bilateral summit: "In times of adversities, from the two financial crises, to major natural disasters such as tsunamis and SARS and to the sudden onslaught of COVID-19, we have always stood together and looked out for each other in the spirit of a community with a shared future" (Li, 2020). Indeed, natural disasters, pandemics, and financial crises serve the same purpose as 'colonialism' and 'underdevelopment' - central world issues that were most commonly invoked during the time of Mao and Deng - in allowing China to claim solidarity and natural affinity with Southeast Asia.

Across the five leaderships, continuity in terms of maintaining a consistent discursive agenda of projecting a unified in-group can be observed. This constitutes China's discourse of unity when it comes to how it perceives Sino-Southeast Asia relations. More specifically, the three discursive themes discussed so far all point to perceived common internal characteristics between the two sides, often emphasizing similarities in ways of life as a result of common roots and experiences. Moving to the last discursive theme that make up China's discourse of unity, China refers to shared goals and dreams, or common destiny, to emphasize why both sides persistently enjoy solidarity therefore in-group unity.

\section{Discourse of Unity: Towards a Common Destiny}

Counting as a fourth discursive theme under China's broad discourse of unity, China's leaders also frequently point to shared trajectories and objectives of maintaining peace and achieving genuine development to emphasize natural affinity with Southeast Asia. If the above three discursive themes emphasize past and present characteristics that have made the in-group naturally constituting, this last discursive theme points to how the in-group shares a common vision of what the future should look like. As Wen Jiabao (2011) has declared in front of ASEAN leaders, both sides "hold similar positions and views, face the same situations and challenges, and pursue the same goals on many key issues".

This fourth discursive theme appeared to be the most common across all five leaderships and the respective texts inspected, albeit adapting with each different contexts. More specifically, while cold war era leaderships under Mao Zedong and Deng Xiaoping tend to focus on China-Southeast Asia unity against an imperialist western bloc, post-cold war era leaderships from Jiang to $\mathrm{Xi}$ on the other hand tend to focus on unity towards establishing and maintaining good-neighborliness within the region. 
During Mao Zedong's leadership, the main shared objective according to leaders would be to categorically oppose western powers and colonialism. Zhou Enlai (1955) for example referred to "complete independence" as the common "objective for which the great majority of Asian and African countries have to struggle for a long time". During this time, much of the common objectives of Asia as described would pertain to the more salient conflict between China and the West, or what China perceives as between arrogant big powers and unwilling victims. As such, China frequently referred to the shared objective of Asia and the 'third world' to mutually "rise against colonialism," to "protect ourselves" from the western powers, and even "jointly propose that [West] hand over their big-power status" (Zhou, 1955; Mao, 1954a).

Although this narrative of going against western major powers grew less salient over time, it was still noticeably present under the leadership of Deng Xiaoping. As reflected in one of Deng's speeches on China's foreign policy, China and Asia jointly maintains an "opposition to hegemonism" as both sides seek to "safeguard world peace" (Deng, 1982). It was also crucial for China during this period to emphasize that the in-group should "depend on ourselves to develop and lift ourselves out of poverty" (Deng, 1988). As evident in these excerpts, the ripe opposition to major powers that was prevalent in official texts during Mao's leadership was gradually being combined with justifications resting on common economic prosperity, and world peace. In succeeding leaderships of Jiang, $\mathrm{Hu}$, and $\mathrm{Xi}$, a gradual change in subject and tone can be observed, where win-win cooperation and regional peace took center-stage as main objectives uniting China and Southeast Asia.

Indeed, succeeding leaderships have introduced foreign policy ideas that go beyond the previous common objective of rising against the West and its perceived legacies of hegemonism or cold war politics, towards a more benign objective of achieving common prosperity . Under Jiang Zemin's leadership, the idea of maintaining good-neighborliness between ASEAN and China was introduced. The concept first appeared in a joint statement released by both parties during the first China-ASEAN Summit in 1997 (ASEAN, 2012). The concept itself stands for peaceful resolution and negotiations among China and ASEAN countries with respect to conflicts, an emphasis on regular bilateral dialogue, and pursuing deeper economic cooperation within the region (Liu and Tsai, 2014). It subsequently appeared in speeches delivered under Jiang's leadership, often describing China-ASEAN relations as jointly pursuing a "good neighborly partnership of mutual trust to the $21^{\text {st }}$ century" (Jiang, 1997; Zhu, 1999). Ensuring discursive continuity with previous leaderships, Zhu Rongji in 1999 has also reiterated that the "partnership of good neighborliness and mutual trust with ASEAN countries" is pursued "on the basis of the Five Principles of Peaceful Co-existence". The Five Principles were proposed by China in 1954, together with India and Myanmar, as guiding principles inspired by the conditions and needs of the developing world in doing international relations.

Beyond the emphasis on good-neighborliness and its component values, the three postCold War leaderships have always articulated pursuing win-win or mutually beneficial cooperation between ASEAN and China as their shared objectives. As Wen Jiabao (2011) has put it, pursuing "economic development and improvement of people's lives" in the region are the "most urgent and important task" for both ASEAN and China. Under the leadership of Hu 
Jintao, there was much emphasis on ASEAN-China relations pursuing deeper economic cooperation (Wen, 2011; Tong, 2011; Li, 2009). This was also the same case for China under $\mathrm{Xi}$ Jinping, where much detail is usually spent on discussing how practical cooperation in various areas, including extensive cooperation via institutional innovations such as the Belt and Road Initiative, have consistently been improving. Indeed, it is this dual focus on ensuring a peaceful environment and deepening economic cooperation in the region, which China has referred to as "a more closely knit China-ASEAN common destiny," that defines a united ingroup according to this discursive theme.

\section{Takeaways}

The sociocognitive process of categorization accounts for China's continuous emphasis on in-group unity. The discourse of unity uncovered in the analysis of the sampled texts shows that China persistently sees itself as belonging in the same in-group with Southeast Asia by virtue of their unique background (e.g. victimhood, histories, experiences), and their common future or destiny. Moreover, this uniqueness in terms of what the two sides share together, makes the in-group distinct from an out-group of western major powers in history led by the United States. This points to self-enhancement at work. Overall, China's discourse of unity toward Sino-Southeast Asia relations allow for a positive representation of China, which speaks of how imperative the region is for China's identity construction as a major power.

\section{Discourses on Relevant Actors: 'Benevolent China' for a 'Developing Southeast Asia'}

This section discusses the predicates and descriptors China has exclusively attached to the remaining subjects-(1) itself, (2) Southeast Asia, and (3) an out-group of western major powers. Similar to the discussion above, this section focuses on identifying continuities and changes that characterize China's respective discourses with respect to these relevant actors.

\section{Benevolent China: Non-hegemonic and Not a 'Threat'}

Across the five leaderships, there has been a consistent trend of presenting China as a benevolent and therefore peace-loving major power. Benevolence (rén 仁) in Chinese philosophy largely refers to one of the core ideas of Confucianism where if applied to foreign policy, tends to emphasize great power empathy and fairness (Yan, 2018). In addition to these values, benevolence also point to a general aversion toward hegemonic behavior and policies (Xu Jin 2011). Indeed, China is well-known for frequently infusing its official speeches and documents on its foreign policy behavior with promises of rejecting hegemonism and of never seeking power politics; the sample of texts in this paper also represent this consistent trend (see Deng, 1982; Jiang, 1997; Zhu, 1999; Hu, 2011; Xi, 2015a).-Yet despite the continuity of stressing the benevolence of the 'Self', China's presentation of this norm has varied across the five leaderships as they emphasize different priorities and experiences. 
For instance, pronouncements made under the cold war era leaderships of Mao and Deng are situated within the rigid ideological competition between the west and China. As such, China's depiction of the self as a benevolent power is often made in explicit comparison with what it perceives to be the immoral or unrighteous legacies of its out-group consisting collectively of western major powers. In fact, it was only during these two leaderships that China often mention the West, or the United States more specifically as a hegemon. And these claims were in direct contrast with China's consistent pledge to non-hegemony. For instance, Deng has once openly accused the West of "practicing hegemonism and sowing discord" among countries in the developing world (Deng, 1982). Likewise, Mao Zedong noted that the United States in particular have "benefited from the two world wars" in terms of its overall progress, while continuing to rely on its "atomic bomb, heavy artillery, and a strong navy and air force" to maintain their dominance of the current international order (Mao, 1954b). He has also often appealed for solidarity with his Asian counterparts, noting that "us people of the East, have been bullied by western imperialist powers" and that the dominance of these "colonial powers" will inevitably face opposition from their victims (Mao 1954a, 1954b). Indeed, it is common for cold war narratives of China's foreign policy as reflected in official speeches to directly highlight the perceived immoralities of the western major power out-group, while depicting China as "hoping for peace more than anything else" (Deng, 1982). Therefore, within the background of intense ideological differentiation between China and its perceived outgroup, China ambitions a benevolent power image by highlighting its benign qualities at the expense of putting the western powers in a bad light. Mentioning its out-group explicitly ensures a clearer picture of the zero-sum comparisons China promotes for itself.

For the post-cold war leaderships on the other hand, these discursive zero-sum comparisons are mentioned less explicitly in official speeches and documents. Yet despite this tamed rhetoric, the spirit of these comparisons remain noticeable in high-level discourses (see Wang, 2013). For example, Jiang Zemin (2000) underscores Chinese benevolence by focusing on its commitment "to promote a multi-polar international configuration" that "differs from the old one in which big powers contend for hegemony and carved up spheres of influence as seen in history". As for more explicit negative descriptions that mention these big powers, in particular the United States, China's responses to specific conflicts and criticisms to its own initiatives provide examples (see Wang, 2015). For instance, China has explicitly accused the United States of "practicing unilateralism and economic hegemony" as it engages in "trade bullyism practices" against China under the previous Trump administration (Information Office of the State Council on the PRC 2018, p. 52). And in former MOFA vice minister He Yafei's book titled China and Global Governance (2019), the distinctions are more explicit as he refers to "the United States and other developed countries in the West [as] having always upheld global governance by the elite class" at the expense of the interests of developing countries (p. 85).

Crucially, China's also argues for its benevolence by highlighting the logic behind a Sino-Southeast Asia in-group and by contrasting its out-group's relationship with the region. For instance, China still harkens back to how Asia is the first to forward the Five Principles in Bandung as they collectively struggled against western "imperialism, colonialism, and 
hegemonism," and how this forged an "Asian way of cooperation" toward "a community of common destiny [that] has increasingly taken shape" in $21^{\text {st }}$ century Asia (Xi, 2015b; Liu, 2014). And in the more focused context of Sino-Southeast Asia relations, China would often remark that "close neighbors are better than distant relatives" to qualify the unique relationship of China and Southeast Asia on the basis of shared histories, common struggles, and common destiny (Xi, 2015b; Zheng, 2005). Being close neighbors also implied that intrusion by western powers in regional affairs prove counterproductive toward "good-neighborly friendship and mutually beneficial cooperation" which has served the in-group well for many years (Huang 2020). Indeed, when it comes to China's discourse of its benevolent self under post-cold war leaderships, China has still referred to implicit categorizations between a China-led in-group and a western-led out-group that emphasizes value-laden narratives of their respective relationships with Southeast Asia.

China has also sought to highlight its benevolence under the post-cold war leaderships by reasserting its commitments to settling disputes fairly, and emphasizing peace and development as the central tenets of its foreign policy. At the same time, narratives of a 'China Threat' also provided added rationale for further emphasis on these objectives. Meant to distort global perceptions on China's rise, this "master narrative" of a 'China Threat' traces its origins from US scholarly and policy debates as well as mass media descriptions, that zoom in on perceived "military and economic threats towards its neighbors and the United States" (Wu 2007, p. 135) As such, China has consistently emphasized throughout these three leaderships that it is a "good neighbor, good friend, and a good partner" to ASEAN despite frequent challenges in their relationship (Jiang, 1997; Wen, 2011; Xi, 2013). In 1998, then vice president Hu Jintao underscored China's commitment in ensuring "friendly consultation on an equal footing" in managing ongoing disputes it has with some ASEAN members. This predication describing China's commitment to an impartial dialogue and negotiation among concerned parties has been a mainstay in the pronouncements of succeeding leaderships (Tong, 2011; Wen, 2011; Xi, 2013; Li, 2020).

Even the cold war leaderships of Mao and Deng have consistently tried to reassure the developing world of its foreign policy trajectories as they always stress that China is "in urgent need of a peaceful international environment for the development of [their] independent and sovereign economy" (Zhou, 1955). Deng Xiaoping's foreign policy doctrine of 'keeping a low profile' has very clear similarities in terms of making a strong connection between peace in the international front, and economic development for China (Pang, 2020). This commitment to international peace for the sake of internal development became more pronounced under the leadership of $\mathrm{Hu}$ Jintao, through the relative institutionalization of the concept of "Peaceful Development" in China's foreign policy doctrine, even going as far as pledging that "China will not deviate from [this] path... even when [it] becomes stronger in the future" (Dai, 2011; also see Zheng, 2005). And while the current academic literature on Xi Jinping's foreign policy has observed that China is increasingly becoming more assertive at the expense of this longstanding peaceful foreign policy doctrine, its official pronouncements still maintain that "China is committed to peaceful development and pursues an independent foreign policy of peace," even claiming it as a doctrine that has been held by China "starting with [their] 
forefathers" (Xi, 2013; Xi, 2015a; Li, 2020). Overall, this narrative of peaceful development not only pose as a counternarrative to the ongoing discourse of a 'China Threat' but it also serve to sharpen the distinction between what China portrays as its benevolent self, and the hegemonic dispositions it has tried so hard to dissociate from since the time of Mao.

In relation to its neighbors in Southeast Asia, China has consistently described itself through discursive themes that highlight its perceived benevolence as a trustworthy partner and ultimately, a good neighbor. As Xu Jin (2011) has noted in his analysis of Mencius' philosophy of benevolent leadership and its applications in understanding Chinese foreign policy, "the various Chinese governments have firmly opposed hegemony and hegemonism... since 1949" thereby in line with how the Pre-qin thinker understood the importance of benevolence (p. 170). Whether this can be observed as being true or not on the ground, for instance with how Southeast Asian nations perceive China's actions, is another topic for discussion. But what is certain is China's persistent commitment in constructing a discourse of itself as a benevolent partner for Southeast Asia.

\section{Developing Southeast Asia and China's Consequential Role}

As what has been observed in the earlier discussion on predicates describing SinoSoutheast Asia relations, China only started substantially referring to Southeast Asia as a group under post-cold war leaderships. In terms of China's frequent descriptions, the predicates uncovered have frequently described Southeast Asia as an economically developing region, which often times struggle in this objective, together with portrayals depicting China as its supportive partner. Ultimately, this combination of consistent predicates seek to depict Southeast Asia as a recipient of a beneficial partnership from China.

The discourse of a 'developing Southeast Asia' intends to emphasize the region's focus on economic development, while also recognizing the relevant progress of the region in this area. Approaching the $21^{\text {st }}$ Century, China's pronouncements often highlight the region's progress in "pressing ahead with its process to attain industrialization, modernization, and integration," as well as in "recovering the economy" after surviving the Asian financial crisis (Jiang, 1997; Hu, 1998). Similarly, this was also the theme for the first decade of the century, as China continues to describe the region as casualty to the "imbalanced development between developing countries and developed counterparts," while also recognizing how the region has been "plagued by serious financial and debt crises" (Li, 2009; Wen, 2011). Likewise, the region's efforts to "address instability and underdevelopment" through "a distinctive ASEAN approach" has been a consistent point of recognition for China in characterizing the development of the region (Xi, 2015a).

Yet it is in this context of presenting Southeast Asia's development experience that China associates itself as having a consequential presence in the fate of the region. For instance, citing financial crises, China claims that its decision "not to devalue its currency" comes from the initiative to "help other Southeast Asian countries" obtain economic recovery (Tong, 2011). Likewise, China would often indicate that it is ASEAN's largest economic partner in terms of overall trade, as well as often the first outside player to come into formal agreements with the 
group (Wen, 2011; Tong, 2011; Xi, 2015a; Li, 2020). As Li Keqiang (2020) has prided, "China has been number one on many fronts among ASEAN's dialogue partners" in terms of "forging strategic partnerships... and giving unequivocal support". China has also been consistently vocal in expressing its support for ASEAN integration as well as supporting ASEAN in taking a more proactive role in regional cooperation in greater East Asia. And when it comes to China's flagship projects such as the BRI and other recent development initiatives, China's leadership has not been shy in declaring the region as "the first to benefit" from these ambitious projects (Xi, 2015a; Li, 2020).

Ultimately, these predications press the discourse of a developing Southeast Asia largely benefiting from sound relations with China. From 'good neighbors' to reliable 'business partners,' China continues to portray in-group solidarity as it presents Southeast Asia in a way that matches its discourse of itself as a benevolent major power.

\section{Takeaways}

The discourses of a 'Benevolent China' and a 'Developing Southeast Asia' also point to categorization and self-enhancement processes at work. In terms of further self-enhancement, China's portrayal as a benevolent power was constructed through comparisons to a western major power out-group, as well as through commitments to principles and norms that challenge major power hegemonism. In terms of further categorization, the discourse of a 'developing Southeast Asia' benefiting from 'benevolent China' seemingly portray a purposeful in-group where peace and development are simultaneously achieved. To this latter point, it can be said that Southeast Asia's relations with China also serves as a valid prototype for its growing ingroup, as China is able to showcase what a non-threatening, benevolent China can mean for developing countries alike.

\section{CONCLUSIONS}

This paper has attempted to uncover China's 'story-telling' of its relations with Southeast Asia on the basis of the theoretical assumptions outlined by Social Identity Theory. As such, this paper sought to contribute to the growing literature on SIT as applied in the discipline of International Relations and Chinese foreign policy in three specific ways. First, it focused on the dual sociocognitive processes of categorization and self-enhancement as indicators of social identity phenomena at work, which existing works on SIT's application in IR have yet to adequately explore. Second, it sought to supplement the existing focus on great power status rivalry and competition as usual points of inquiry, and focused more on how such status rivalry can be manifested in specific relationships and policy areas such as SinoSoutheast Asia relations, as opposed to broad arenas of grand strategies and international norms which hitherto have been the focus of inquiry in this growing research area. And lastly, this paper has also provided analytical evidence indicating that Sino-Southeast Asia relations is being treated by China preferentially and in SIT language, prototypically as an in-group stereotype worth emulating (Hogg et al, 2005). Therefore, this paper systematically provides evidence on how the prototyping dimension of social identity phenomenon can also be explored 
within interstate dynamics. And in this specific case, it was shown that China portrays its relations with Southeast Asia as hard evidence of its benevolence towards developing countries. This last point also has several implications for existing and future research on Sino-Southeast Asia Relations.

In terms of being portrayed as a prototypical in-group consistent with SIT assumptions, it can be said that China is also trying to send the message to prospective members of its growing in-group, ideally developing countries adhering to its normative causes, that a mutually beneficial relationship with benevolent China is possible. Indeed, this observed dynamics of prototyping Southeast Asia is also consistent with the Xi administration's focus on the region in terms of its relative significance within China's neighborhood policy. Likewise, it also echoes existing studies highlighting a step-wise process to China's "grand strategy to reshape the regional order in Asia, and eventually the global order with new ideas, norms, and rules for IR and global governance" (Song, 2020, p. 245; also see Callahan, 2016, Reeves, 2018). China has constructed a story of a 'Benevolent China' united with 'Developing Southeast Asia' to provide a positive representation of itself in light of its continuous rise to great power status.

From this story-telling, it can be said that China has indeed benefited from Southeast Asia ideationally as much as 'developing Southeast Asia' has materially benefited from China. Given the important role of Sino-Southeast Asia relations in China's overall pursuit for and presentation of a positive identity, it is highly likely that the region will continue to be a crucial strategic as well as diplomatic focus of China. The relatively fast disbursement of donated vaccines for COVID-19 in the region is a recent example of this continuing prioritization. Likewise, it could also be likely that China leverages on this grand story of Sino-Southeast Asian unity it has constructed ever since in moments where its benevolence is being questioned, most particularly when it comes to territorial conflicts with specific Southeast Asian countries, to shed light on the good and downplay the unpleasant. Perhaps as a next step for observers interested in inspecting this dynamics further, potential gaps and consistencies in terms of actions and discourses of Southeast Asia's role in China's foreign policy can also be examined.

Overall, this paper has highlighted the centrality of a pursuit for a positive and distinct identity in China's foreign policy. China aspires to be perceived differently vis-à-vis other western major powers in history, and it has sought this alternative image by forwarding norms and values in international relations that it perceives to be unique, which allows it to construct a discourse of itself as a benevolent major power. In terms of how identity is manifested in discourse, it is also clear that China has referred to a discourse of deep cultural and historical affinity with Southeast Asia, as it argues for natural familiarity, thereby allowing it to paint a picture of a major power cut from the same thread as Southeast Asia. In this way, China's benevolence can be easily appreciated. But Southeast Asia as a region ought to be wary. As this study has shown, China is indeed a discourse power as Song (2020) has emphasized. China actively utilizes historical narratives and recollections of particular experiences in highlighting a certain reading of how the region has fared in the face of a rising China. The power also lies with small countries in the region. China's preferred discourses will only have sufficient power and believability if subjects being depicted, as well as audiences targeted, lend meaning to 
these messages and proclaim them to be accurate as well. In this sense, China's aspiration for a distinct and positive image is not a one-way street - Southeast Asia can be a grateful partner, as well as an impartial auditor of China's longstanding identity ambitions.

\section{ABOUT THE AUTHORS}

Enrico V. Gloria is an Assistant Professor at the Department of Political Science, University of the Philippines Diliman. His areas of interests include Chinese foreign policy, Philippine foreign policy, foreign policy discourses, and major power status. He obtained his Master of Laws (Politics) degree from Tsinghua University, and his Bachelor's Degree (Economics) from UP Diliman.

\section{REFERENCES}

Aoyama, R. (2013). Chinese Diplomacy toward Neighboring Countries. Journal of Contemporary East Asia Studies, 2(2): 73-93.

Association of Southeast Asian Nations. (2012). Joint Statement of the Meeting of Heads of State/Government of the Member States of ASEAN and the President of the People's Republic of China Kuala Lumpur, Malaysia, 16 December 1997. Retrieved February 03, 2021, from https://asean.org/?static_post=joint-statement-of-the-meeting-of-headsof-stategovernment-of-the-member-states-of-asean-and-the-president-of-the-people-srepublic-of-china-kuala-lumpur-malaysia-16-december-1997

Beeson, M., \& Li, F. (2012). Charmed or Alarmed? Reading China's regional relations. Journal of Contemporary China, 21(73), 35-51.

Boon, H. (2017). Hardening the Hard, Softening the Soft: Assertiveness and China's Regional Strategy. Journal of Strategic Studies 40(5): 639-662.

Callahan, W. (2016). China's “Asia Dream'”: The Belt Road Initiative and the new regional order. Asian Journal of Comparative Politics 1(3): 226-243.

Cheng, J. (1999). China's ASEAN Policy in the 1990s: Pushing for Regional Multipolarity. Contemporary Southeast Asia 21(2), 176-204.

Crouch, M., and McKenzie, H. (2006) The logic of small samples in interview-based qualitative research', Social Science Information, 45(4): 483-99.

Dai, B. (2011). China is Committed to the Path of Peaceful Development. Retrieved February 03, 2021, from https://www.fmprc.gov.cn/mfa_eng/wjdt_665385/zyjh_665391/t860218.shtml

Deng, X. (1982). China's Foreign Policy. In D. Xiaoping (Ed.), Selected Works of Deng Xiaoping: Volume 2 (1975-1982). Retrieved February 03, 2021, from https://dengxiaopingworks.wordpress.com/2013/02/25/chinas-foreign-policy/ 
Deng, X. (1988). A New International Order Should Be Established With the Five Principles of Peaceful Coexistence As Norms. In D. Xiaoping (Ed.), Selected Works of Deng Xiaoping: Volume 3 (1982-1992). Retrieved February 03, 2021, from https://dengxiaopingworks.wordpress.com/2013/03/18/a-new-international-ordershould-be-established-with-the-five-principles-of-peaceful-coexistence-as-norms/

Deng, X. (1990). The International Situation and Economic Problems. In D. Xiaoping (Ed.), Selected Works of Deng Xiaoping: Volume 3 (1982-1992). Retrieved February 03, 2021, from $\quad$ https://dengxiaopingworks.wordpress.com/2013/03/18/the-internationalsituation-and-economic-problems/

Foucault, M. (2010). The Archaeology of Knowledge and The Discourse on Language. A.M. Sheridan Smith (Trans.). New York: Vintage Books. (Original work published 1969).

Gloria, E. (2020). Constructing Major Power Identity: China's Discourses on the Belt and Road Initiative and Policy Insights for the Philippines. In Arugay, A., \& Kraft, H. (Eds.), Toward an Enhanced Strategic Policy in the Philippines (pp. 87-106). Quezon City : University of the Philippines, Center for Integrative Studies

Goh, E. (2014). The Modes of China's Influence: Cases from Southeast Asia. Asian Survey 54(5): 825-848.

Hogg, M., Deborah T., \& White, K. (1995). A Tale of Two Theories: A Critical Comparison of Identity Theory with Social Identity Theory. Social Psychology Quarterly 58, 25569.

$\mathrm{Hu}$, J. (1998). Address by Vice President Hu Jintao at China-ASEAN Informal Leadership Meeting. Retrieved February 03, 2021, from https://www.fmprc.gov.cn/zdjn/eng/zywj/t270547.htm

Huang, R. (2020). Keep Abreast of the Right Side of History to Achieve Common Development in the Challenging World. Retrieved May 12, 2021, from http://ph.chinaembassy.org/eng/sgxx/dsjh/t1818455.htm

Huong, L. (2019). China's dual strategy of coercion and inducement towards ASEAN. Pacific Review, 32(1): 20-36.

Information Office of the State Council The PRC. (2018). The Facts and China's Position on China-U.S. Trade Friction. Retrieved February 03, 2021, from http://www.xinhuanet.com/english/2018-09/24/c_137490176.htm

Jiang, Z. (1997). Towards a Good-Neighbourly Partnership of Mutual Trust Oriented to the $21^{\text {st }} \quad$ Century. Retrieved February 03, 2021, from https://www.fmprc.gov.cn/zdjn/eng/zywj/t270546.htm

Jiang, Z. (2000). Statement by President Jiang Zemin of the People's Republic of China at the Millenium Summit of the United Nations. Retrieved May 12, 2021. from https://www.fmprc.gov.cn/mfa_eng/wjdt_665385/zyjh_665391/t24962.shtml 
He, K. \& Feng, H. Xi Jinping's Operational Code Beliefs and China's Foreign Policy, The Chinese Journal of International Politics, 6(3): 209-231.

Kim, E. (2014). Rising China and Turbulent East Asia: Asianization of China? Pacific Focus: Inha Journal of International Studies, 29(1): 1-7.

Koremenos, B., Lipson, C., \& Snidal, D. (2001). The rational design of international institutions. International Organization, 55(2), 761-799.

Larson, D. (2017). Social Identity Theory: Status and Identity in International Relations. In W. Thompson (Ed.), The Oxford Encyclopedia of Empirical International Relations Theory. Oxford University Press. Retrieved February 03, 2021, from https://oxfordre.com/politics/view/10.1093/acrefore/9780190228637.001.0001/acrefor e-9780190228637-e-290

Larson, D., and Shevchenko, A. (2010). Status Seekers: Chinese and Russian Responses to U.S. Primacy. International Security 34, 63-95.

Lee, J. (2016). Will China's Rise Be Peaceful? A Social Psychological Perspective. Asian Security 12, 29- 52 .

Li, K. (2009). Full text of Vice Premier Li Keqiang at 6th China-ASEAN Business and Investment Summit. Retrieved February 03, 2021, from http://ph.chinaembassy.org/eng/zt/ASEAN/t895035.htm

Li, K. (2013). Chinese Premier Li Keqiang's Keynote Speech at 10th China-ASEAN Expo. Retrieved May 09, 2021, from http://id.china-embassy.org/eng/sgdt/t1073252.htm

Li, K. (2020a). Speech by H.E. Li Keqiang Premier of the State Council of the People's Republic of China at the $23^{\text {rd }}$ China-ASEAN Summit. Retrieved February 03, 2021, from http://english.www.gov.cn/premier/speeches/202011/13/content_WS5fade6dbc6d0f72 $\underline{57693 f 972 . h t m l}$

Li, K. (2020b). Speech by H.E. Li Keqiang Premier of the State Council of The People's Republic of China at the Third Lancang-Mekong Cooperation Leaders' Meeting. Retrieved February 03, 2021, from http://eg.chinaembassy.org/eng/zgyw/t1808937.htm

Li, M. (2019). China's Foreign Policy in Xi's Era: Change and Continuity. Retrieved February 03, 21, from https://cids.up.edu.ph/publications/discussion-papers/2019-series/2019$\underline{05 /}$

Li, X. (2015). Applying offensive realism to the rise of China: structural incentives and Chinese diplomacy toward the neighboring states. International Relations of the Asia-Pacific, 16(2): 241-271. 
Lindgren, W., \& Lindgren, P. (2017). Identity Politics and the East China Sea: China as Japan's 'Other': China as Japan's Other. Asian Politics \& Policy 9: 378-401.

Liu, T., \& Tsai, T. (2014). Swords into ploughshares? China's Soft Power strategy in Southeast Asia and its challenges. Revista Brasileira de Política Internacional 57, Retrieved February 03, 2021, from https://www.scielo.br/scielo.php?script=sci_arttext\&pid=S003473292014000300028\&lng=en\&tlng=en

Mao, Z. (1954a). Minutes of Chairman Mao Zedong's First Meeting with Nehru. Wilson Center Digital Archive. October 19, 1954. Retrieved February 03, 2021, from https://digitalarchive.wilsoncenter.org/document/117825

Mao, Z. (1954b). Minutes of Chairman Mao Zedong's First Meeting with Nehru. Wilson Center Digital Archive. October 23, 1954. Retrieved February 03, 2021, from https://digitalarchive.wilsoncenter.org/document/117815

Mao Z. (1963). Memorandum of Chairman Mao Zedong's Conversation with Prince Sihanouk. Wilson Center Digital Archive. February 15, 1963. Retrieved February 03, 2021, from https://digitalarchive.wilsoncenter.org/document/117953

Ministry of Foreign Affairs of the People's Republic of China (2013). Special China-ASEAN Foreign Ministers' Meeting Held in Beijing. Retrieved 09 May 2021 from https://www.fmprc.gov.cn/mfa_eng/wjb_663304/wjbz_663308/activities_663312/t10 $\underline{72011 . s h t m l}$

MOFA PRC (2014). Chairman Mao Zedong's Theory on the Division of the Three World and the Strategy of Forming an Alliance Against an opponent. Retrieved February 03, 2021, from

https://www.fmprc.gov.cn/mfa_eng/ziliao_665539/3602_665543/3604_665547/t1800 $\underline{8 . \operatorname{shtml}}$

MOFA PRC (2015). Foreign Minister Wang Yi Meets the Press. Retrieved May 12, 2021, from https://www.fmprc.gov.cn/mfa_eng/zxxx_662805/t1243662.shtml

Pang, Z. (2020). From Tao Guang Yang Hui to Xin Xing: China's Complex Foreign Policy Transformation and Southeast Asia. Retrieved February 03, 2021, from https://www.iseas.edu.sg/wp-content/uploads/2020/04/TRS7_20.pdf

Parameswaran, P. (2019). China's Military Ambitions in Southeast Asia: Much Bigger than Cambodian Bases. The Diplomat. Retrieved 09 May 2021. https://thediplomat.com/2020/10/chinas-military-ambitions-in-southeast-asia-muchbigger-than-cambodian-bases/

Patton, M. Q. (2015). Qualitative Research and Evaluation Methods: Integrating Theory and Practice $\left(4^{\text {th }}\right.$ ed $)$. Thousand Oaks, CA: Sage. 
Qin, Y. (2014). Continuity through Change: Background Knowledge and China's International Strategy. The Chinese Journal of International Politics, (7)3: 285-314.

Reeves, J. (2018). Imperialism and the Middle Kingdom: the Xi Jinping administration's peripheral diplomacy with developing states, Third World Quarterly 39(5): 976-998.

Ruiz, J. R. (2009). Sociological Discourse Analysis: Methods and Logic. Forum: Qualitative Social Research, 10(2), Art. 26, http://nbn-resolving.de/urn:nbn:de:0114-fqs0902263.

Rüland, J., \& Michael, A. (2019). Overlapping regionalism and cooperative hegemony: how China and India compete in South and Southeast Asia. Cambridge Review of International Affairs, 32(2): 178-200.

Schreier, M. (2018) Sampling and Generalization. In U. Flick (Ed.), The Sage Handbook of Qualitative Collection (pp. 84-99). London: Sage Publications

Smith, S. (2021). Harmonizing the periphery: China's neighborhood strategy under Xi Jinping, The Pacific Review 34 (1): 56-84.

Song, W. (2020). China's Normative Foreign Policy and Its Multilateral Engagement in Asia. Pacific Focus: Inha Journal of International Studies 35(2): 229-249.

Storey, I. (2012). China's Bilateral Defense Diplomacy in Southeast Asia. Asian Security, 8(3): 287-310.

Strangio, S. (2020). China's Southeast Asian 'Vaccine Diplomacy' Comes Into Relief. Retrieved February 03, 2021, from https://thediplomat.com/2020/11/chinas-southeastasian-vaccine-diplomacy-comes-into-relief/

Stromseth, J. (2019). The Testing Ground: China's Regional Influence in Southeast Asia and Regional Responses. Brookings (Report). https://www.brookings.edu/research/thetesting-ground-chinas-rising-influence-in-southeast-asia-and-regional-responses/

Suehiro, A. (2017). China's offensive in Southeast Asia: regional architecture and the process of Sinicization. Journal of Contemporary East Asia Studies, 6(2): 107-131.

Tajfel, H and Turner, J. (1986). The Social Identity Theory of Intergroup Behavior. In S. Worshel \& W. Austin (Eds.), Psychology of Intergroup Relations (pp. 276-93). Chicago: Nelson Hall.

Takahara, A. (2012). The Rise of China and Its Neighborhood Diplomacy: Implications for Japanese Foreign Policy. Journal of Contemporary East Asia Studies, 1(1): 47-71.

Tan, C., \& Maulia, E. (2020). Red Pill? Behind China's COVID-19 vaccine diplomacy: Southeast Asia bargains with Beijing for lifesaving drugs. Retrieved February 03, 2021, from https://asia.nikkei.com/Spotlight/The-Big-Story/Red-Pill-Behind-China-sCOVID-19-vaccine-diplomacy 
Tong, X. (2011). China-ASEAN: A model of good-neighborliness and friendly co-op. Retrieved February 03, 2021, from http://www.china.org.cn/opinion/201107/03/content_22911782.htm

Van Dijk, T. (1993). Principles of Critical Discourse Analysis. Discourse \& Society 4(2): 249283.

Van Dijk, T.A. (2001). Multidisciplinary CDA: a plea for diversity. In R. Wodak \& M. Meyer (Eds)., Methods of Critical Discourse Analysis (pp. 95-121). Sage Publications.

Wen, J. (2011). Statement by H.E. Wen Jiabao Premier of the State Council of the People's Republic of China At the 14th China-ASEAN Summit as a Commemorative Summit To Celebrate the 20th Anniversary of China-ASEAN Relations. Retrieved February 03, 2021, from http://ph.china-embassy.org/eng/zt/ASEAN/t895072.htm

Wodak, R. (2001). What CDA is about - a summary of its history, important concepts and its developments. In R. Wodak \& M. Meyer (Eds)., Methods of Critical Discourse Analysis (pp. 1-14). Sage Publications.

Wodak, R. (2001). The discourse-historical approach. In R. Wodak \& M. Meyer (Eds)., Methods of Critical Discourse Analysis (pp. 63-94). Sage Publications.

Wong, L. (2007). China-ASEAN and Japan-ASEAN Relations during the Post-Cold War Era. Chinese Journal of International Politics 1(3), 373-404.

Wang, Y. (2013). Toward a New Model of Major-Country Relations Between China and the United States. Retrieved May 12, 2012. from https://www.fmprc.gov.cn/mfa_eng/wjdt_665385/zyjh_665391/t1078768.shtml

Wu, C. (2007). Barking Up the Wrong Tree? The Master Narrative of "China Threat Theory" Examined, In S. Guo \& B. Guo (Eds)., Challenges Facing Chinese Political Development (pp. 111-142). Lanham: Lexington Books

Xi, J. (2013). Speech by Chinese President Xi Jinping to Indonesian Parliament. Retrieved February 03, 2021, from http://www.asean-china-center.org/english/201310/03/c_133062675.htm

Xi, J. (2015). Xi Jinping's speech at National University of Singapore. Retrieved February 03, 2021, from http://www.whcy.ynu.edu.cn/info/1128/1275.htm

Xi, J. (2015b).https://www.fmprc.gov.cn/mfa_eng/wjdt_665385/zyjh_665391/t1250690.shtml. $\begin{array}{llll}\text { Retrieved } \quad \text { May } & \text { 12, 2021, from }\end{array}$ https://www.fmprc.gov.cn/mfa_eng/wjdt_665385/zyjh_665391/t1250690.shtml

Xinbo, W. (2016). Cooperation, competition and shaping the outlook: the United States and China's neighbourhood diplomacy. International Affairs, 92(4): 849- 867. 
Xu, J. (2011). The Two Poles of Confucianism: A Comparison of the Interstate Political Philosophies of Mencius and Xunzi. In X. Yan (Ed.), Ancient Chinese Thought, Modern Chinese Power (pp. 161-180). New Jersey: Princeton University Press.

Yan, X. (2018). Chinese Values vs. Liberalism: What Ideology Will Shape the International Normative Order? Chinese Journal of International Politics 11(1): 1-22.

Zheng, B. (2005). China's Peaceful Rise: Speeches of Zheng Bijian. Washington, D.C.: Brookings University Press.

Zhou E. (1955). Main Speech by Premmier Zhou Enlai, Head of the Delegation of the People's Republic of China. Retrieved February 03, 2021, from https://digitalarchive.wilsoncenter.org/document/121623

Zhu, R. (1999). Address by Premier Zhu Rongji of the People's Republic of China at the ASEAN+1 Informal Summit 28 November 1999. Retrieved February 03, 2021, from https://asean.org/?static_post=address-by-premier-zhu-rongji-of-the-people-srepublic-of-china-at-the-asean1-informal-summit-28-november-1999 